\title{
The effect of peripheral administration of ghrelin on the performance of growing geese
}

\author{
H. Aghdam Shahryar ${ }^{1}$ and A. Lotfi ${ }^{2}$ \\ ${ }^{1}$ Department of Animal Science, Shabestar Branch, Islamic Azad University, Shabestar, Iran \\ ${ }^{2}$ Ilkhchi Branch, Islamic Azad University, Ilkhchi, Iran \\ Correspondence to: H. Aghdam Shahryar (ha_shahryar@yahoo.com)
}

Received: 16 August 2014 - Accepted: 26 March 2015 - Published: 26 May 2015

\begin{abstract}
The purpose of the present study is to investigate the effect of intraperitoneal (IP) injection of ghrelin on goose performance. Hence, forty-eight 28-day-old geese were assigned into three treatments which lasted 40 days. The first intact group included no injection; that is, treatment 1 was characterized by G0; treatment 2 , given to the second intact group, was characterized by $\mathrm{G} 50,50 \mathrm{ng} \mathrm{kg}^{-1}$ ghrelin body weight (BW); and treatment 3 , given to the third intact group, was characterized by G100, $100 \mathrm{n} \mathrm{kg}^{-1}$ ghrelin BW. Ghrelin was injected at the outset of the experimental rearing period (28-day-old birds). Blood samples were taken at two different times: (1) $12 \mathrm{~h}$ after the injection and (2) at the end of the rearing period. The effects of the injections were examined and evaluated during two rearing periods (28-48 days old and 48-68 days old). In the second treatment (G50), ghrelin injection caused an increase in the feed intake during the growing period but not the finishing period. Body weight gain and feed conversion ratio (FCR) of the growing period and finishing period did not change following any ghrelin treatments $(P>0.05)$. Injection of ghrelin at $\mathrm{G} 100$ increased breast muscle (pectoral) weight. The results of the present study indicate that ghrelin has a significant impact on feeding regulation and muscle growth at a certain period in geese. Nevertheless, it should be noted that ghrelin may have different effects on feeding of avian species.
\end{abstract}

\section{Introduction}

It has been 16 years since ghrelin was discovered in animals (Kojima et al., 1999). Related studies and experiments have demonstrated numerous physiological functions for ghrelin, namely growth-hormone-releasing activity (Hashizume et al., 2005), appetite regulation, weight gain/loss and energy balance (Nakazato et al., 2001; Toshinai et al., 2003; Vizcarra et al., 2007). Chicken ghrelin was formed with 26 amino acids and was initially identified by Kaiya et al. (2002). Ghrelin has been identified in six species of birds including chicken, emu, turkey, goose, duck and Japanese quail (Kaiya et al., 2008). A possible impact of ghrelin on chickens' growth was studied in Lotfi et al. (2011, 2013). Although it has been demonstrated that ghrelin has a growth-hormonereleasing activity in mammalian and non-mammalian vertebrates, like chickens, it might also cause particular physiological functions such as food intake inhibition in birds
(Kaiya et al., 2013). Therefore, it can be maintained that birds can be regarded as good models for studying and examining the general functions and impacts of ghrelin on vertebrates.

When ghrelin is injected centrally or peripherally, it consistently stimulates appetite in humans (Wren et al., 2001a) and rats (Wren et al., 2001b; Toshinai et al., 2007). Nevertheless, the hypothetical impact of ghrelin on bird food intake is deemed to be a research issue which has created a lot of controversial debates and arguments among interested scholars. Some studies (Furuse et al., 2001; Saito et al., 2002) have revealed that the central injection of ghrelin inhibits food intake in chickens. A dose-dependent stimulatory or inhibitory effect of ghrelin on food intake was investigated on Japanese quail (Shousha et al., 2005). Research studies have indicated that the peripheral administration of ghrelin in broiler chickens causes an inhibitory effect on feed intake (Geelissen et al., 2006; Buyse et al., 2009; Ocłon and Pietras, 2011); however, this effect was not observed on layer-type 
chickens (Kaiya et al., 2007). A brief review of the related literature reveals that, so far, the effect of exogenous ghrelin on feeding has been investigated only on two species of birds, namely chickens and quail. This issue is considered to be a significant research gap. Hence, in order to fully understand and characterize the general and specific impact as well as immediate and subsequent impact and function of ghrelin on feeding regulation, researchers should carry out independent and full-scale studies on a range of different species of birds. In an initial study in goose, the possible ghrelin effect on endocrine hormones was investigated by Aghdam Shahryar et al. (2014). Such studies can be considered as evidence for the potential role of ghrelin in goose metabolism and feed intake, and it forms a background for the present study.

With regard to the above-mentioned research gap, the researchers in the present study investigated the effect of exogenous ghrelin on the following important factors: feed intake; body weight gain (BWG); feed conversion ratio (FCR); carcass characteristics; and biochemical parameters such as glucose, total cholesterol and triglyceride in growing geese.

\section{Material and methods}

The study reported in this paper was conducted in poultry research station of Iranian agricultural research center in the province of East Azerbaijan in the northwest of Iran. The sample of the study included forty-eight 28-day-old domestic geese (Anser anser domesticus) (BW: $650 \mathrm{~g} \pm 35$ ); they were selected randomly and were further assigned into three treatments. Each treatment group included four birds and four replicates. Sixteen floor pens (four pens for each treatment and four birds for each pen) were used as the context for housing the sample chickens during the experimental rearing period. Moreover, according to the design of the study, feed was made available ad libitum. The lighting program was arranged according to commercial goose farming ( $8 \mathrm{~h}$ light, $16 \mathrm{~h}$ dark for 28-day-old birds, up to end of experiment).

\subsection{Injection procedure}

The lyophilized rat ghrelin was purchased from SigmaAldrich Co. (USA), dissolved in $1 \%$ solvent (acetic acid solvent according to the Sigma brochure) and diluted with distilled water to the desired amount. Pre-experimental tests showed that injecting acetic acid (as a solvent) did not have any biological effect on performance and the related parameters (Lotfi et al., 2013). Ghrelin was injected (IP: intraperitoneal) at the onset of the experimental rearing phase (28day-old birds). The injected doses were as follows: treatment 1 (G0), intact group without any injection; treatment 2 (G50), $50 \mathrm{ng} \mathrm{kg}^{-1}$ ghrelin body weight (BW); and treatment 3 (G100), $100 \mathrm{ng} \mathrm{kg}^{-1}$ ghrelin BW. The injected volume for each bird (single injection) was $0.5 \mathrm{~mL}$.
Table 1. Ingredients and nutrient specifications of experimental diets for geese.

\begin{tabular}{|c|c|}
\hline Item & Growth period (28-68d) \\
\hline \multicolumn{2}{|l|}{ Ingredient, $\%$} \\
\hline Corn & 52.93 \\
\hline Wheat & 25.00 \\
\hline Soybean meal & 16.8 \\
\hline Wheat bran & 2.00 \\
\hline Bone meal & 1.13 \\
\hline Oyster meal & 1.34 \\
\hline Vitamin-mineral premix* & 0.50 \\
\hline Lysine & 0.04 \\
\hline Methionine & 0.06 \\
\hline Salt & 0.20 \\
\hline \multicolumn{2}{|l|}{ Compositions (calculated) } \\
\hline $\operatorname{ME}\left(\mathrm{kcal} \mathrm{kg}^{-1}\right)$ & 2990 \\
\hline Crude protein, $\%$ & 14.97 \\
\hline $\mathrm{Ca}, \%$ & 0.60 \\
\hline $\mathrm{P}$ available, $\%$ & 0.30 \\
\hline \multicolumn{2}{|c|}{$\begin{array}{l}\text { * Supplied per kilogram of diet: } 6050 \mu \mathrm{g} \text { vitamin } \mathrm{A} \text { (retinyl acetate }+ \\
\text { retinyl palmitate), } 55 \mu \mathrm{g} \text { vitamin } \mathrm{D}_{3}, 22.05 \mu \mathrm{g} \text { vitamin } \mathrm{E}(\alpha \text {-tocopheryl } \\
\text { acetate), } 2.0 \mathrm{mg} \text { vitamin } \mathrm{K}_{3}, 5 \mathrm{mg} \text { vitamin } \mathrm{B}_{1}, 6.0 \mathrm{mg} \text { vitamin } \mathrm{B}_{2}, 60 \mathrm{mg} \\
\text { vitamin } \mathrm{B}_{3}, 4 \mathrm{mg} \text { vitamin } \mathrm{B}_{6}, 0.02 \mathrm{mg} \text { vitamin } \mathrm{B}_{12}, 10.0 \mathrm{mg}, \text { pantothen } \\
\text { acid, } 6.0 \mathrm{mg} \text { folic acid, } 0.15 \mathrm{mg} \text { biotin, } 0.625 \mathrm{mg} \text { ethoxyquin, } 500 \mathrm{mg} \\
\mathrm{CaCO}, 80 \mathrm{mg} \mathrm{Fe}, 80 \mathrm{mg} \mathrm{Zn}, 80 \mathrm{mg} \mathrm{Mn}, 10 \mathrm{mg} \mathrm{Cu}, 0.8 \mathrm{mg} \mathrm{I} \text {, and } 0.3 \mathrm{mg} \\
\text { Se. }\end{array}$} \\
\hline
\end{tabular}

\subsection{Diets}

Diets were formulated according to NRC (1994) recommendations (Table 1), which were used for all birds during the experimental period (from day 28 to 68). Body weight and feed intake were recorded at two points, i.e., days $28-48$ and days $48-68$, to determine the growing performance.

\subsection{Carcass yield and serum biochemical assays}

On day 28 ( $12 \mathrm{~h}$ after the injection of ghrelin) and also at the end of the rearing experiment (on day 68), two birds from each replicate of the treatments with a BW (basic weight) close to that of the mean replicate were selected. Then, blood samples were collected from their wing veins using sterilized syringes. The blood was centrifuged $\left(1200 \mathrm{~g}, 7 \mathrm{~min}, 18^{\circ} \mathrm{C}\right)$ and the serum was prepared for the determination of some biochemical parameters of the blood (glucose, total cholesterol and triglyceride) with an Alcyon 300 autoanalyzer (Abbott Park, IL., USA) and its commercial kits (Pars Azmoon kits, Pars Azmoon Inc., Tehran).

In order to determine the final features and characteristics of the carcass yields, 68-day-old birds were slaughtered. Carcass weights, pectoral muscle, thigh, liver and abdominal fat were measured and calculated by dividing the weight of each mentioned organ into individual BW on day 68 . The effect of ghrelin injection on feed intake, BWG and FCR was investigated at two phases; that is, like common broiler production 
Table 2. Performance of geese subjected to IP injection of ghrelin.

\begin{tabular}{|c|c|c|c|c|c|c|c|}
\hline \multicolumn{2}{|l|}{ Treatment } & \multicolumn{3}{|c|}{ Growing period day $28-48$} & \multicolumn{3}{|c|}{ Finishing period day $48-68$} \\
\hline & $\begin{array}{l}\text { Injection } \\
\text { dosage } \\
\left(\mathrm{ng} \mathrm{kg}^{-1} \mathrm{BW}\right)\end{array}$ & Feed intake $(\mathrm{g})$ & $\mathrm{BWG}^{1}(\mathrm{~g})$ & $\mathrm{FCR}^{2}$ & Feed intake $(\mathrm{g})$ & BWG (g) & FCR \\
\hline Intact (control) & 0 & $1483.3 \pm 8.4$ & $810.0 \pm 28.1$ & $1.83 \pm 0.08$ & $1984.7 \pm 68.5$ & $631.7 \pm 33.4$ & $3.14 \pm 0.41$ \\
\hline G50 & 50 & $1582.7 \pm 9.2$ & $943.6 \pm 34.2$ & $1.67 \pm 0.07$ & $2308.3 \pm 77.4$ & $665.0 \pm 31.8$ & $3.47 \pm 0.28$ \\
\hline G100 & 100 & $1531.7 \pm 8.7$ & $858.7 \pm 27.5$ & $1.78 \pm 0.08$ & $2066.7 \pm 71.6$ & $663.1 \pm 33.1$ & $3.11 \pm 0.34$ \\
\hline$P$ value & & 0.5295 & 0.1305 & 0.212 & 0.5606 & 0.9552 & 0.4854 \\
\hline
\end{tabular}

${ }^{1}$ BWG: body weight gain. ${ }^{2}$ FCR: feed conversion ratio.

Table 3. Carcass traits ${ }^{1}$ of geese subjected to IP injection of ghrelin.

\begin{tabular}{lllllll}
\hline Treatments & $\begin{array}{l}\text { Injection dosage } \\
\left(\mathrm{ng} \mathrm{kg}^{-1} \mathrm{BW}\right)\end{array}$ & $\begin{array}{l}\text { Carcass yield } \\
(\%)\end{array}$ & $\begin{array}{l}\text { Breast muscle } \\
(\%)\end{array}$ & $\begin{array}{l}\text { Thigh } \\
(\%)\end{array}$ & $\begin{array}{l}\text { Abdominal fat } \\
(\%)\end{array}$ & $\begin{array}{l}\text { Liver } \\
(\%)\end{array}$ \\
\hline Intact (control) & 0 & $62.50 \pm 3.2$ & $18.30^{\mathrm{b}} \pm 0.3$ & $25.10 \pm 1.8$ & $4.30 \pm 0.5$ & $3.23 \pm 0.9$ \\
G50 & 50 & $60.67 \pm 3.4$ & $18.26^{\mathrm{b}} \pm 0.3$ & $25.86 \pm 1.8$ & $4.46 \pm 0.5$ & $4.46 \pm 0.8$ \\
G100 & 100 & $59.53 \pm 3.5$ & $19.43^{\mathrm{a}} \pm 0.5$ & $28.63 \pm 1.9$ & $4.96 \pm 0.7$ & $4.96 \pm 0.9$ \\
$P$ value & & 0.530 & 0.006 & 0.073 & 0.645 & 0.645 \\
\hline
\end{tabular}

${ }^{\mathrm{a}-\mathrm{b}}$ Means with different letters are different $(P<0.05)$.

${ }^{1}$ Carcass characterizations are presented with percent of carcass weight.

studies, it was examined during the growth period (day 2848 ) and the finishing period (day 48-68). The experimental procedures of this study were conducted with regard to the recommendations of the animal ethics committee of the veterinary department of the Islamic Azad University.

\subsection{Statistical analyses of the results}

In this study, the experiment was designed based on complete randomization of sample birds. The GLM procedure was used for analysis with SAS statistical analysis software (SAS Inst. Inc., Cary, NC, 2000). The significance of difference among the experimental groups (treatments) was investigated by means of the Tukey test. The probability value was set at $P<0.05$ for checking the statistical significance of difference among the independent groups. The statistical model is given below:

$Y_{i j}=\mu+T_{i}+E_{i j}$

where $Y_{i j}$ represents all dependent variables, $\mu$ is the overall mean, $T_{i}$ is the effect of ghrelin levels $(i=1,2,3)$ and $E_{i j}$ is the random effect of the residual.

\section{Results}

Feed intake, BWG and goose FCR are given in Table 2. Ghrelin administration at a low dose (G50) caused an increase in feed intake for the growing period. However, it was not significant between groups $(P>0.05)$. Also, there were no significant differences between BWG and FCR $(P>0.05)$. In the finishing period, when compared with control group, there was a growing tendency in feed intake of the experimental groups. However, no differences were observed in BWG and FCR $(P>0.05)$.

Table 3 shows the effect of IP injection of rat ghrelin on carcass traits in 68-day-old geese. It had no significant effect on carcass components such as carcass yield, thigh and abdominal fat, except for breast muscle, which had an increase in response to $\mathrm{G} 100$ ghrelin administration $(P<0.01)$.

Table 4 illustrates the effect of IP injection of rat ghrelin on biochemical characteristics of serum in goose. IP injection of rat ghrelin had no significant effect on serum glucose, total cholesterol and triglyceride for 48- or 68-day-old geese.

\section{Discussion}

As noted earlier in the study, research findings on the impact of goose ghrelin are overwhelmingly limited. Li et al. (2007) found that ghrelin-producing cells exist in the mucosal layer of the small intestine of adult white geese. Ghrelin-producing cells were found in metabolic and gastrointestinal organs such as the proventriculus, intestine, liver and pancreas of geese (Eidaroos et al., 2008; Fugui et al., 2008). Regarding ducks, it has been found that there is a correlation between the ghrelin gene and ghrelin receptor with lipid metabolism and fat deposition (Nie et al., 2009). In an initial study on goose, Aghdam Shahryar et al. (2014) found that ghrelin had a significant impact on endocrine hormones. These reports 
Table 4. Serum biochemical characterizes in geese subjected to IP injection of ghrelin.

\begin{tabular}{|c|c|c|c|c|c|c|c|}
\hline \multirow[t]{2}{*}{ Treatment } & & \multicolumn{3}{|c|}{ Day 28} & \multicolumn{3}{|c|}{ Day 68} \\
\hline & $\begin{array}{l}\text { Injection } \\
\text { dosage } \\
\left(\mathrm{ng} \mathrm{kg}^{-1} \mathrm{BW}\right)\end{array}$ & $\begin{array}{l}\text { Glucose } \\
\left(\mathrm{mg} \mathrm{dL}^{-1}\right)\end{array}$ & $\begin{array}{l}\text { Total } \\
\text { cholesterol } \\
\left(\mathrm{mg} \mathrm{dL}^{-1}\right)\end{array}$ & $\begin{array}{l}\text { Triglyceride } \\
\left(\mathrm{mg} \mathrm{dL}^{-1}\right)\end{array}$ & $\begin{array}{l}\text { Glucose } \\
\left(\mathrm{mg} \mathrm{dL}^{-1}\right)\end{array}$ & $\begin{array}{l}\text { Total } \\
\text { cholesterol } \\
\left(\mathrm{mg} \mathrm{dL}^{-1}\right)\end{array}$ & $\begin{array}{l}\text { Triglyceride } \\
\left(\mathrm{mg} \mathrm{dL}^{-1}\right)\end{array}$ \\
\hline Control & 0 & $201.00 \pm 5.5$ & $162.75 \pm 10.9$ & $193.25 \pm 16.2$ & $210.00 \pm 13.7$ & $247.25 \pm 11.0$ & $241.22 \pm 16.2$ \\
\hline G50 & 50 & $192.00 \pm 8.2$ & $152.50 \pm 9.9$ & $240.75 \pm 30.3$ & $210.75 \pm 7.6$ & $231.00 \pm 8.3$ & $260.71 \pm 17.0$ \\
\hline G100 & 100 & $182.25 \pm 7.2$ & $168.00 \pm 9.9$ & $221.25 \pm 33.7$ & $225.00 \pm 11.3$ & $240.97 \pm 10.4$ & $231.25 \pm 23.0$ \\
\hline$P$ value & & 0.138 & 0.574 & 0.365 & 0.583 & 0.099 & 0.152 \\
\hline
\end{tabular}

can be considered as evidence for the potential role of ghrelin in goose metabolism and feed intake.

The results of the present study revealed that ghrelin administration at a low dose stimulated feed intake. However, it seems that ghrelin had a transitory effect; that is, although it did had a positive effect on FCR and BWG at the finishing period, it was not significant $(P>0.05)$. An acute stimulatory effect of ghrelin on feed intake was reported by Shousha et al. (2005) with IP injection of ghrelin $(0.4-0.9 \mathrm{nmol} / 100 \mathrm{~g} \mathrm{BW})$ in Japanese quail. The result of the present study is partially similar to Shousha et al. (2005) in that IP-injected ghrelin may affect afferent vagal nerves as a hunger signal (Date et al., 2001) and cause an acute stimulation of feed intake in geese.

When compared with the control group, intraperitoneal ghrelin injection at a greater dose (100 $\mathrm{ng} \mathrm{kg}^{-1}$ ghrelin BW) increases feed intake, but the difference is not significant $(P>0.05)$. Previous studies have indicated that centrally injected rat ghrelin has a transient inhibitory effect on feed intake in neonatal chicks (Furuse et al., 2001; Saito et al., 2002). Shousha et al. (2005) argued that a greater dose of ghrelin may have a down-regulating effect on growthhormone-releasing activity and is saturated following the administration of a high dose of ghrelin. In the present study, it seems that a high dose of ghrelin may have a similar effect and could counteract a possible stimulatory effect of the vagal nerves. On the whole, IP injection of ghrelin did not have any considerable effect on feeding performance of the entire rearing period $(P>0.05)$. The finding of this study might be comparable to the study conducted on layer chickens (Kaiya et al., 2007). In other words, peripheral administration of ghrelin does not have any significant effect on feed intake.

As shown in Table 3, ghrelin administration at a high dose (G100) increases breast muscle weight. This effect might be attributed to GH-releasing effect of peripheral ghrelin (Kaiya et al., 2002; Baudat and Harvey, 2003). This effect may be more pronounced in muscular tissue such as pectoral muscle. In this regard, within ovo-injection of another growthstimulating peptide (insulin-like growth factor 1: IGF-I), Deprem and Gulmez (2007) reported increases in embryonic development of musculus longus colli dorsalis in Japanese quail. This finding suggests that ghrelin could stimulate muscle growth via the stimulation of the GH-IGF-I axis.

Although it has been documented that lower level of IGFI is a stimulating factor for ghrelin synthesis (Stawerska et al., 2012) and chronic elevation of ghrelin activates the GHIGF-I axis (Iwakura et al., 2009; Ho, 2011), further studies should be conducted to clarify this issue. It was found that a low dose of ghrelin was not sufficient for enhancing breast muscle weight in geese. With regard to other carcass features, (carcass yield, thigh, abdominal fat, liver), increased peripheral ghrelin did not cause any significant effects.

Peripheral administration of ghrelin has no stimulatory or inhibitory effect on goose feed intake in the total rearing period. However, a low dose of ghrelin indicated a transient stimulatory effect on feed intake in the growing period. Administration of a high ghrelin dose may increase breast muscle weight in the finishing period. This study suggested ghrelin roles in food intake in different avian species; however, it might show a different effect on food intake. Further studies should investigate the physiological significance of ghrelin in geese.

Acknowledgements. This paper was reported based on a research project supported by the Shabestar branch of the Islamic Azad University. The authors are grateful to H. Kaiya (Department of Biochemistry, National Cerebral and Cardiovascular Center Research Institute) for his technical help and contributions to this research study.

Edited by: K. Wimmers

Reviewed by: three anonymous referees

\section{References}

Aghdam Shahryar, H., Ghiasi Ghalehkandi, J., Lotfi, A., and Chekani-Azar, S.: Effect of peripheral administration of ghrelin on serum insulin, T3, T4 and some biochemical parameters in geese, Biol. Forum, 6, 100-102, 2014. 
Baudat, M. L. and Harvey, S.: Ghrelin-induced GH secretion in domestic fowl in vivo and in vitro, J. Endocrinol., 179, 97-105, 2003.

Buyse, J., Janssen, S., Geelissen, S., Swennen, Q., Kaiya, H., Darras, V. M., and Dridi, S.: Ghrelin modulates fatty acid synthase and related transcription factor mRNA levels in a tissuespecific manner in neonatal broiler chicks, Peptides, 30, 13421347, 2009.

Date, Y., Nakazato, M., Murakami, N., Kojima, M., Kangawa, K., and Matsukura, S.: Ghrelin acts in the central nervous system to stimulate gastric acid secretion, Biochem. Bioph. Res. Co., 280, 904-907, 2001.

Deprem, T. and Gulmez, N.: The effects of in ovo insulin-like growth factor- 1 on embryonic development of musculus longus colli dorsalis in Japanese quail, Turk. J. Vet. Anim. Sci., 31, 233240, 2007.

Eidaroos, H., Yoshimura, Y., and Helmy, S. A.: Distribution of the Ghrelin Hormone Producing Cells in the Gastro-intestinal Tract of Some Birds (Immunohistochemical Study), J. Vet. Anat., 1, 14-21, 2008.

Fugui, F., Meiqing, L., Yong, T., Shudong, J., and Fuba, L.: Immunohistochemical localization of ghrelin in the liver and pancreas of adult Wanxi white goose, Chinese J. Anat., S858, p. 33, 2008.

Furuse, M., Tachibana, T., Ohgushi, A., Ando, R., Yoshimatsu, T., and Denbow, D. M.: Intracerebroventricular injection of ghrelin and growth hormone releasing factor inhibits food intake in neonatal chicks, Neurosci. Lett., 301, 123-126, 2001.

Geelissen, S. M. E., Swennenb, Q., Van der Geyten, S., Kuhn, E. R., Kaiya, H., Kangawa, K., Decuypere, E., Buyse, J., and Darras, V. M.: Peripheral ghrelin reduces food intake and respiratory quotient in chicken, Domest. Anim. Endocrin., 30, 108-116, 2006.

Hashizume, T., Horiuchia, M., Nonakaa, S., Kasuyab, E., Kojimac, M., Hosodad, H., and Kangawa, K.: Effects of ghrelin on growth hormone secretion in vivo in ruminants, Regul. Peptides, 126, 61-65, 2005.

Ho, K.: Growth hormone related diseases and therapy, in: Ghrelin in the regulation of GH secretion and other pituitary hormones, 1st, edited by: Lanfranco, F., Baldi, M., Motta, G., Minetto, M. A., Marotta, F., Gasco, V., and Ghigo, E., Humana Press - Springer, Berlin, 21 pp., 2011.

Iwakura, H., Ariyasu, H., Li, Y., Kanamoto, N., Bando, M., Yamada, G., Hosoda, H., Hosoda, K., Shimatsu, A., Nakao, K., Kangawa, K., and Akamizu, T.: A mouse model of ghrelinoma exhibited activated GH-IGF-I axis and glucose intolerance, American J. Physiol. Endocrinol. Metabol., 297, E802-E811, 2009.

Kaiya, H., Van der Geyten, S., Kojima, M., Hosoda, H., Kitajima, Y., Matsumoto, M., Geelissen, S., Darras, V. M., and Kangawa, K. M.: Chicken ghrelin: purification cDNA cloning and biological activity, Endocrinology, 143, 3454-3463, 2002.

Kaiya, H., Saito, E. S., Tachibana, T., Furuse, M., and Kangawa, K.: Changes in ghrelin levels of plasma and proventriculus and ghrelin mRNA of proventriculus in fasted and refed layer chicks, Domest. Anim. Endocrin., 32, 247-259, 2007.

Kaiya, H., Miyazato, M., Kangawa, K., Peter, R. E., and Unniappan, S.: Ghrelin: a multifunctional hormone in non-mammalian vertebrates, Comp. Biochem. Phys. A, 149, 109-128, 2008.
Kaiya, H., Kangawa, K., and Miyazato, M.: What is the general action of ghrelin for vertebrates? - Comparisons of ghrelin's effects across vertebrates. Gen. Comp. Endocr., 18, 187-191, 2013.

Kojima, M., Hosoda, H., Date, Y., Nakazato, M., Matsuo, H., and Kangawa, K.: Ghrelin is a growth-hormone-releasing acylated peptide from stomach, Nature, 402, 656-660, 1999.

Li, F., Fang, F., Li, M., Tu, J., Yong, T., Shu-dong, J., and Ly, P.: Immunohistochemical localization of ghrelin in the small intestine of adult Wanxi white Goose, Acta Vet. Zootec. Sin., 38, 206208, available at: http://118.145.16.233/Jweb_xmsy/EN/Y2007/ V38/I2/206, 2007.

Lotfi, A., Aghdam Shahryar, H., Ghiasi Ghaleh-Kandi, J., Kaiya, H., and Ahmadzadeh, A.: In ovo administration of ghrelin and subsequent prolactin level in newly hatched chicks, J. Poult. Sci., 48, 130-132, 2011.

Lotfi, A., Aghdam Shahryar, H., and Kaiya, H.: Effect of in ovo ghrelin administration on hatching results and post-hatching performance of broiler chickens, Livest. Sci., 154, 158-164, 2013.

Nakazato, M., Murakami, N., Date, Y., Kojima, M., Matsuo, H., Kangawa, K., and Matsukura, S.: A role for ghrelin in the central regulation of feeding, Nature, 409, 194-198, 2001.

Nie, Q., Fang, M., Xie, L., Peng, X., Xu, H., Luo, C., Zhang, D., and Zhang, X.: Molecular characterization of the ghrelin and ghrelin receptor genes and effects on fat deposition in Chicken and Duck, J. Biomed. Biotech., 2009, 567120, doi:10.1155/2009/567120, 2009.

NRC.: Nutrition requirement of poultry, 9th rev. ed., National Academy Press, Washington, D.C., 1994.

Ocłoń, E. and Pietras, M.: Peripheral ghrelin inhibits feed intake through hypothalamo-pituitary-adrenal axis-dependent mechanism in chicken, J. Anim. Feed Sci., 20, 118-130, 2011.

Saito, E. S., Kaiya, H., Takagi, T., Yamasaki, I., Denbow, D. M., Kangawa, K. and Furuse, M.: Chicken ghrelin and growth hormone releasing peptide- 2 inhibit food intake of neonatal chicks, Euro J. Pharmacol., 453, 75-79, 2002.

SAS Institute: SAS_User's Guide, SAS Institute Inc., Cary, NC, 2000.

Shousha, S., Nakahara, K., Kojima, M., Miyazato, M., Hosoda, H., Kangawa, K., and Murakami, N.: Different effects of peripheral and central ghrelin on regulation of food intake in the Japanese quail, Gen. Comp. Endocrin., 141, 178-183, 2005.

Stawerska, R., Smyczynska, J., Czkwianianc, E., Pisarek, H., Hilczer, M., and Lewinski, A.: Ghrelin concentration is correlated with IGF-I/IGFBP-3 molar ratio but not with GH secretion in children with short stature, Neuroendocrinol. Lett., 33, 412418, 2012.

Toshinai, K., Date, Y., Murakami, N., Shimada, M., Mondal, M., Shimbara, T., Guan, J. L., Wang, Q. P., Funahashi, H., Sakurai, T., Shioda, S., Matsukura, S., Kangawa, K., and Nakazato, M.: Ghrelin-induced food intake is mediated via the orexin pathway, Endocrinology, 144, 1506-1512, 2003.

Toshinai, K., Mondal, M. S., Shimbara, T., Yamaguchi, H., Date, Y., Kangawa, K., and Nakazato, M.: Ghrelin stimulates growth hormone secretion and food intake in aged rats, Mech. Ageing Dev., 128, 182-186, 2007.

Vizcarra, J. A., Kirby, J. D., Kim, S. K., and Galyean, M. L.: Active immunization against ghrelin decreases weight gain and alters plasma concentrations of growth hormone in growing pigs, Domest. Anim. Endocrin., 33, 176-189, 2007. 
Wren, A. M., Seal, L. J., Cohen, M. A., Brynes, A. E., Frost, G. S., Murphy, K. G., Dhillo, W. S., Ghatei, M. A., and Bloom, S. R.: Ghrelin enhances appetite and increases food intake in humans, J. Clin. Endocrinol. Metabol., 86, 5992-5995, 2001a.
Wren, A. M., Small, C. J., Abbott, C. R., Dhillo, W. S., Seal, L. J., Cohen, M. A., Batterham, R. L., Taheri, S., Stanley, S. A., Ghatei, M. A., and Bloom, S. R.: Ghrelin causes hyperphagia and obesity in rats, Diabetes, 50, 2540-2547, 2001b. 